\title{
Fragments of a buried urban past revealed through multi-layered voids hidden below the mosque of St. Daniel: the case of the underground museum in Tarsus
}

\author{
M. Cetin ${ }^{1}$ \& S. Doyduk ${ }^{2}$ \\ ${ }^{I}$ Department of Architecture, Yeditepe University, Turkey \\ ${ }^{2}$ Department of Architecture, Yildiz Technical University, Turkey
}

\begin{abstract}
The historical process of urban-architectural layering in cities appears to accentuate the role of the intersections between various networks of urban circulation and public spaces from different eras. One of these spaces was recently unearthed in southern Turkey, where many civilizations have accumulated over the course of time. This underground building complex consists of cavities in addition to the remains of the foundations of a 16th century Ottoman bath, as well as the tomb of St. Daniel next to a Roman bridge vault that were recently excavated below 19th century Makam Mosque in Tarsus. The spatial formation here displays an extraordinarily complicated three dimensional stratification below the ground. This paper begins with historical research and analysis of space and continues with a design proposal to fuse all the religious, historical, geographical, architectural, spatial and material content into a single tectonic entity. Therefore, in summary, the paper addresses the issues of multi faceted design criteria regarding tangible and intangible aspects, and further discusses the issues such as; how such physical contexts enable multiple readings of history through spatial configuration, how geometrical grammar operates to narrate the history of urban stratification and how state-ofthe-art architectural and engineering technology co-exist in historic contexts.
\end{abstract}

Keywords: urban archaeology, architecture, conservation, space, tomb of St. Daniel, museum, Tarsus, Turkey. 


\section{Introduction}

Tarsus is a town located in the southern part of Turkey, and has been a major settlement centre during the civilisations of Rome, Cilicia, Seljuk and the Ottoman empires [1-3]. Thus, it has witnessed a comprehensive urban stratification throughout the ages, which elevated the current altitude (in other words, ground level) of the city approximately $7 \mathrm{~m}$ above its original level during Roman times [4,5]. The archaeological excavations conducted in and around the $19^{\text {th }}$ century Makam-i Daniel mosque revealed a complex spatial structure (Fig.1) of an underground spatial configuration (Fig.2) dating from periods such as the $1^{\text {st }}, 7^{\text {th }}, 13^{\text {th }}, 16^{\text {th }}$, and $19^{\text {th }}$ centuries A.D. Local authorities, and the conservation council demanded a genuine design solution developed to restore, conserve and to display these findings as they have special religious significance, particularly for Jewish and Muslim communities as well as visitors to the tomb of St. Daniel. Such a design should not only critically interpret and abstract the ongoing process of urban layering, but also contribute to such formation via its spatial and geometrical organisation. One of the major problems was in organising this space as a multi-religious cultural centre, while an associated problem was to unite sub-ground levels with ground floor facilities. Another problem was to construct a protective cover without obstructing the existing mosque building, which is of a significant local heritage.

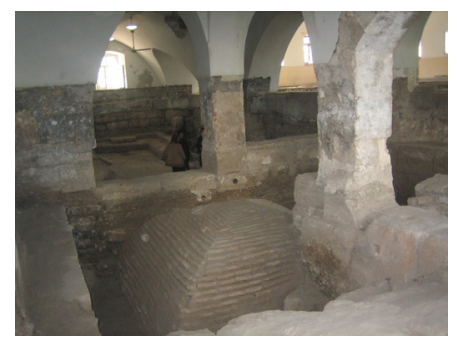

Figure 1: Archaeological findings of the tomb of St. Daniel below the ground level of the $19^{\text {th }}$ century Makam mosque in Tarsus.

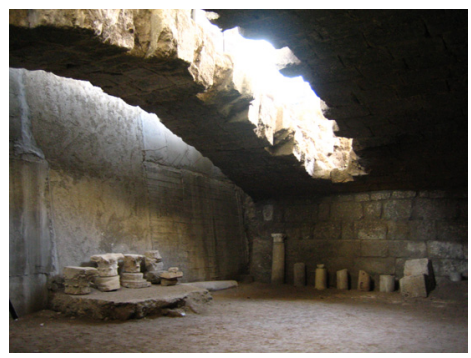

Figure 2: Underground archaeological space to be converted to an exhibition hall. 
Finally problems regarding the construction within the historic tissue and within the underground context, places the significance of the project onto an architectural version of intricate implant surgery.

\section{Architectural intervention as an implant surgery to the archaeological tissue}

The design proposal tackled this set of major problems; firstly, through various methods of archaeological analyses [6-9], and secondly, through a comprehensive survey of existing building and archaeological voids. The study further included a thorough review of precedents of such visionary projects. Therefore, the project consisted of both restoration work [10-13], and an architectural addition [14-17], which is also required to accommodate contemporary facilities for a museum of urban archaeology.

The project addresses the issue of utilization of this underground archaeological space as an intervention [18-24], the design concept of which manifests itself in the form of a museum of archaeology wrapping around a sacred core conserved in its authentic location. Hence, a unique spatial experience is intended whereby divine content and historical substance are intertwined into a ceremonial and mysterious hybrid of the multi-cultural physical context. Architectural design not only attempts to achieve a new and exciting sub-ground-level urban void, but also to equip a pedestrian node as an integral part of the urban living environment [25-29]. The architectural design theme is composed of a simple, neutral steel shell and wide glass screens as a protective structure (Fig.3) over the intricate labyrinth of interconnected subground spaces. It also regulates the spatial experience around a spinal

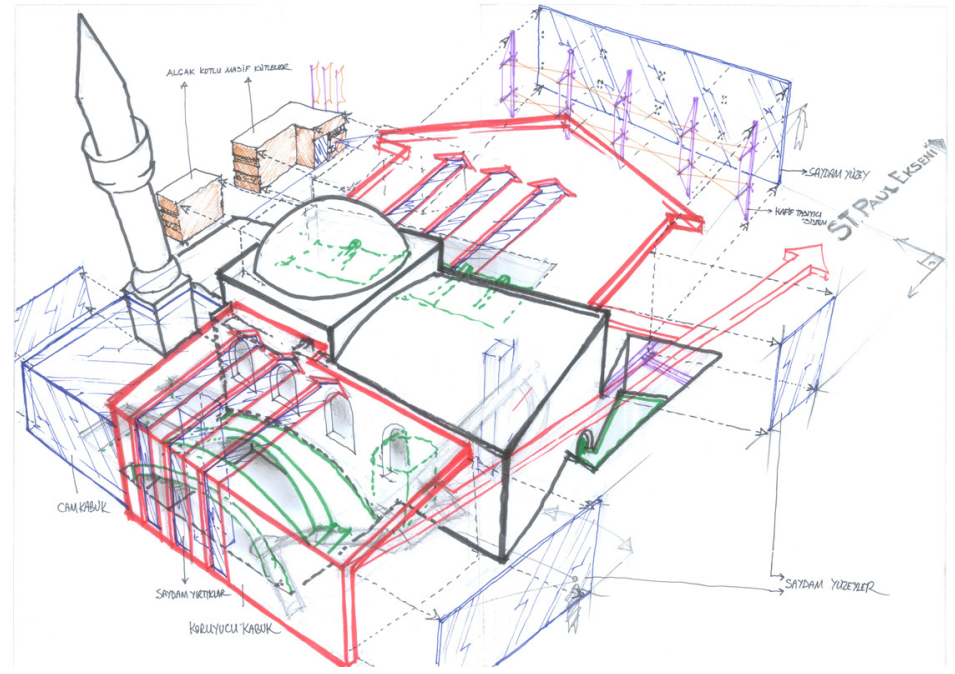

Figure 3: Schema illustrating the principles of the protective shell over the underground archaeological space. 


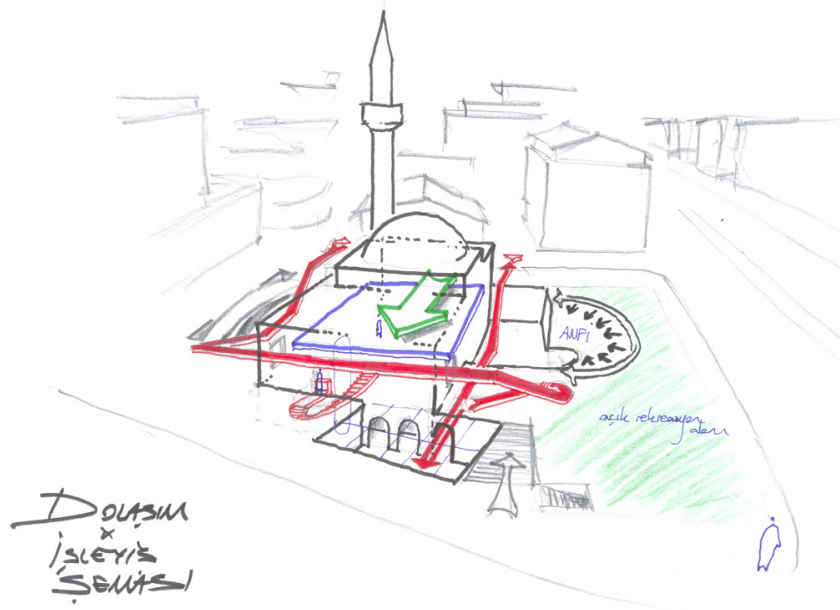

Figure 4: Circulation scheme of the proposed underground museum.

component, that is to say, an uninterrupted three dimensional circulation path (Fig.4) via steel and glass decks and bridges laid out so as to unveil the historical layering through human movement.

The design proposal re-interprets the underlying grammar [30] of the process of urban stratification through the geometry of the new addition. It develops a composition based on the geometrical superimposition in accordance with dominant urban axes and orientation of existing spatial configuration (Fig.5). This addition is basically a protective shell (Fig.6), uniting spaces both below and above the ground, including interior and exterior spaces that accommodate archaeological remains from different eras. The shell is double layer structure, accommodating a void allocated for technical services (electrical and mechanical facilities) in between the two peripheries. It is a steel construction clad with composite pre-oxidised copper panel sheets on the exterior, and with compact laminated panels on the interior. On the other hand, the circulation path is constructed in the form of steel ramps and bridges, the surface material of which ranges from wood, to laminated glass and, in some places, to metal mesh depending on the quality of the space underneath the platform. The path follows a route starting from the north of the original mosque that not only surrounds it from three sides, but also dynamically locates the visitor to the different levels in this three dimensional labyrinth-like spatial configuration. The principles of transparency and permeability [31,32] have been the two major motives in the formation of these two architectonic components (Fig.7) as the means of honouring the heritage via judicious intervention of contemporary elements.

\section{Conclusion}

The public demand for the utilisation of a masterpiece of cultural heritage consisting of architectural spaces and underground archaeological remains is 

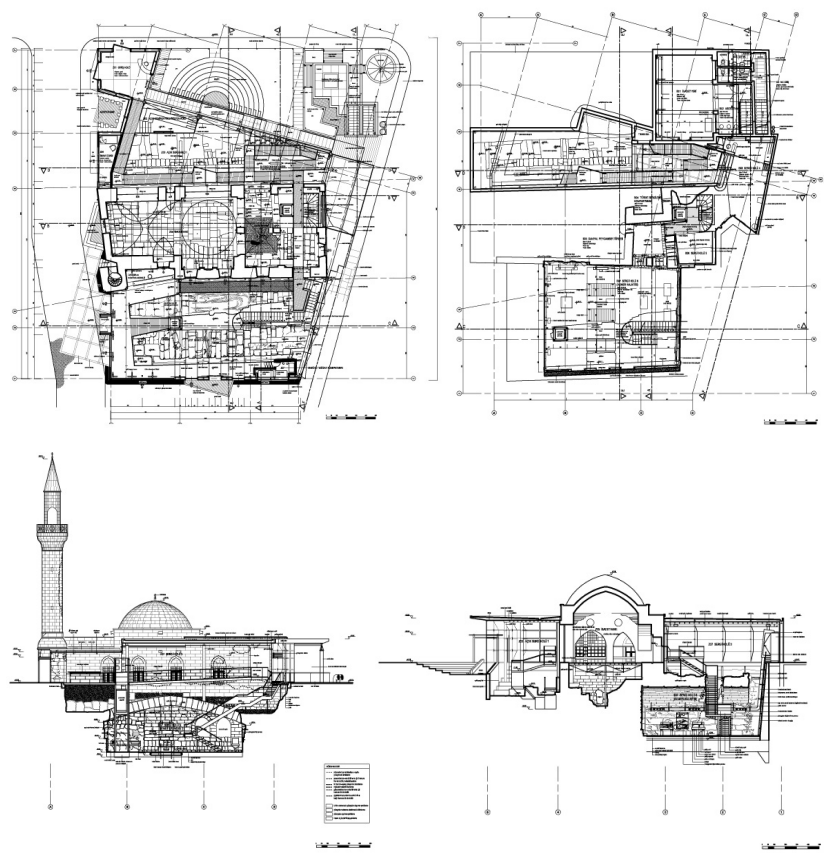

Figure 5: $\quad$ Plans and sections of the proposed museum building.

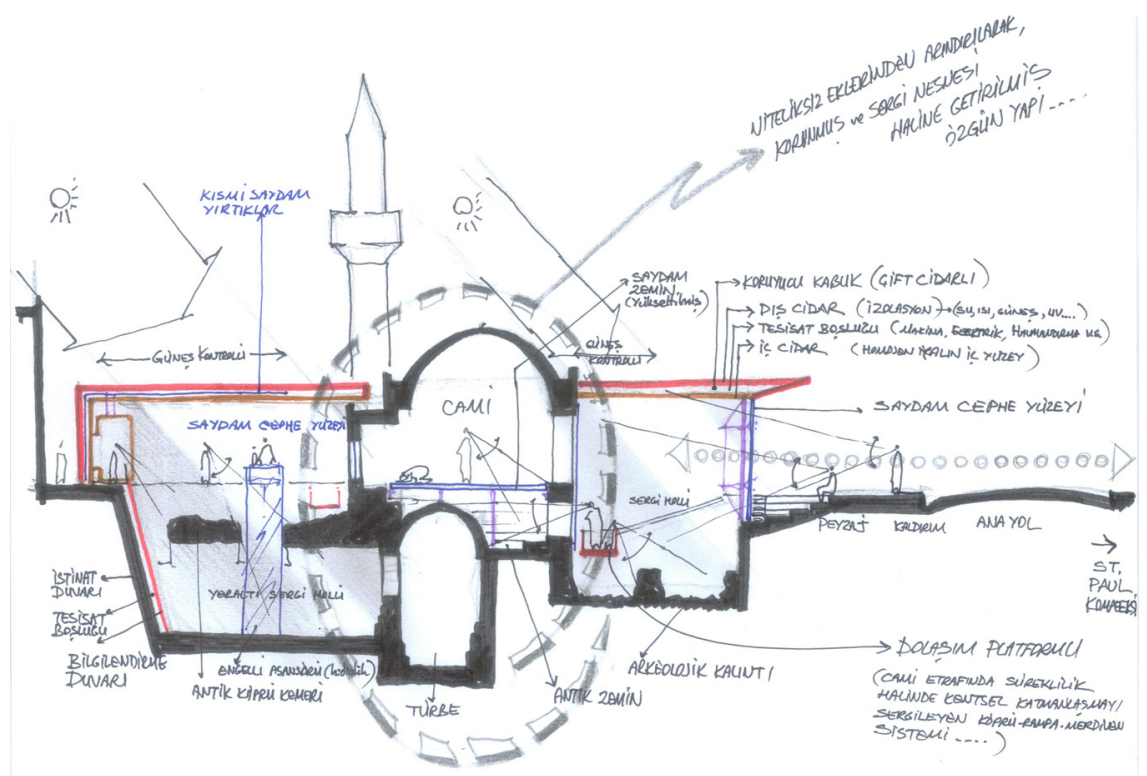

Figure 6: Section showing the 3D quality of the underground space. 


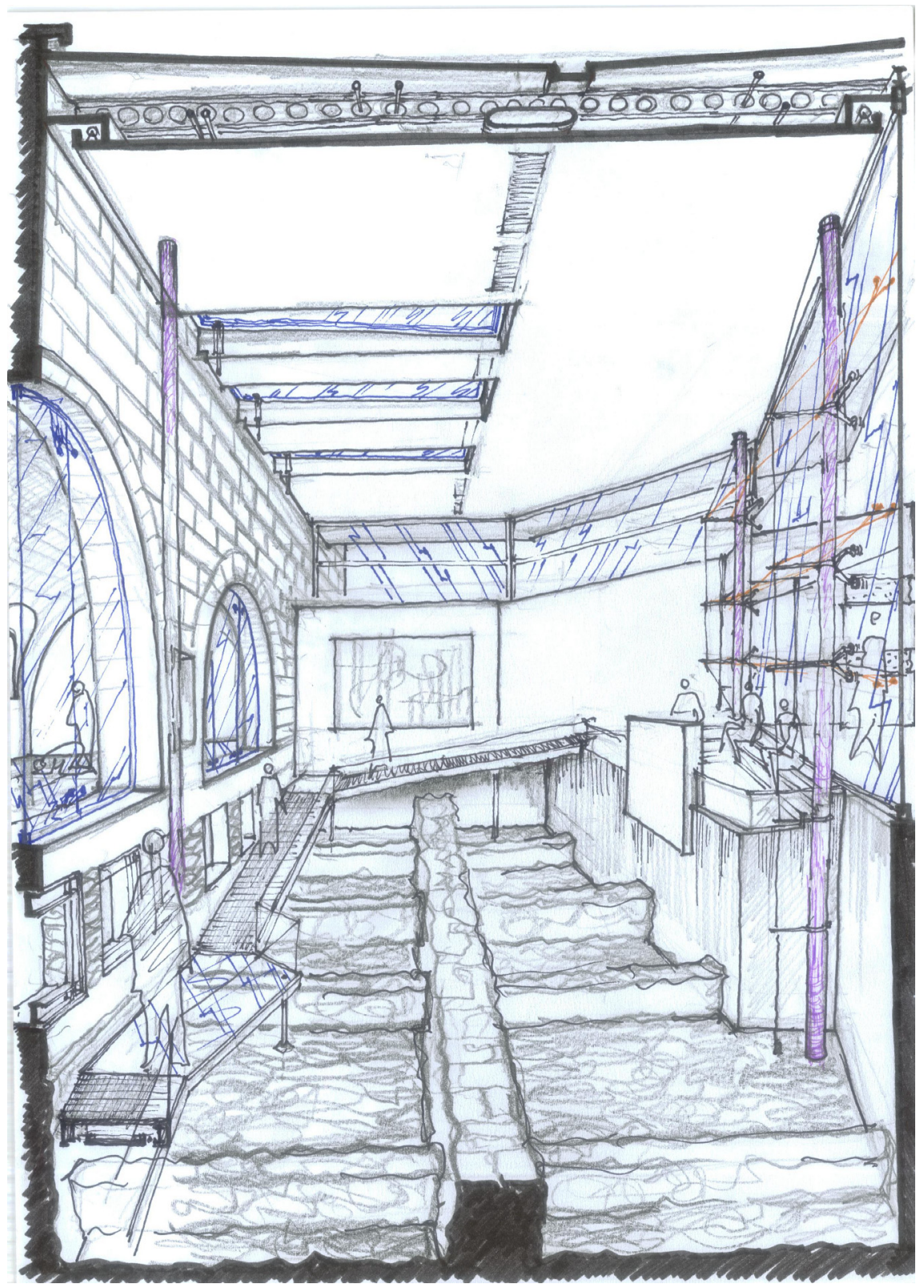

Figure 7: Sketch showing the transparent and permeable spatial quality of proposed underground museum. 

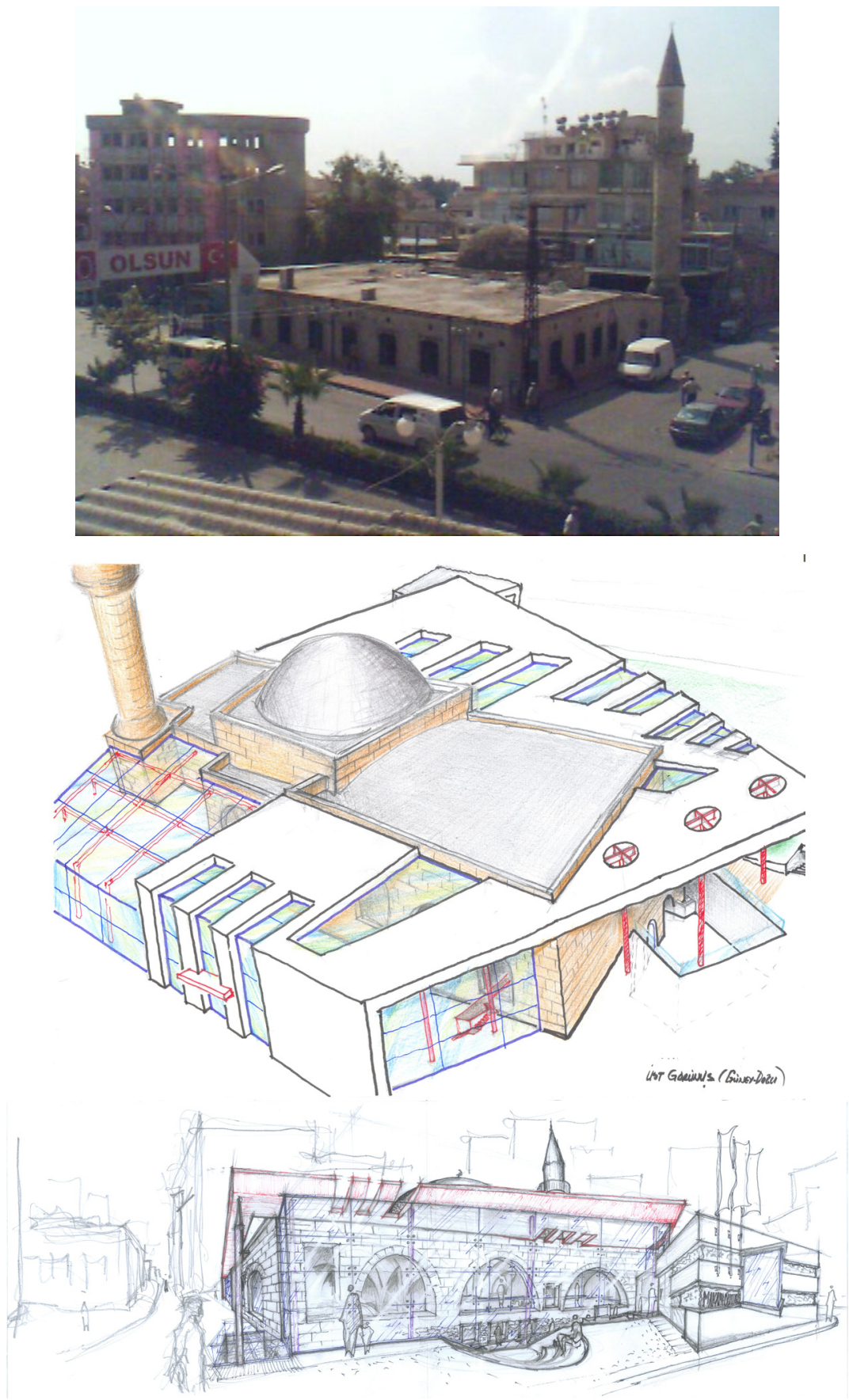

Figure 8: $\quad$ Existing outlook of the mosque and sketch of proposed museum.

WIT Transactions on the Built Environment, Vol 102, (C) 2008 WIT Press

www.witpress.com, ISSN 1743-3509 (on-line) 
addressed by means of the above discussed design project. In this framework, underground historical remains are integrated with current urban life [33] through the design proposal. Moreover, fragments of the urban history of the town of Tarsus are deciphered through the movement of visitors among the historical layers of the urban stratification within the three dimensional underground space which is intertwined with the architectural spaces above the ground around this mosque (Fig.8). The intended aesthetics of hybrid design, reconciling; old and new, tradition and innovation, conventional typology and technology, as well as spaces below and above layers of ground [34] are searched for within the intersection area of the disciplines of contemporary architectural-engineering design and heritage conservation. Thus, an existing complicated spatial asset that is located in a multi-cultural geography is further improved within a multi-disciplinary synthesis. Consequently, the historical continuity of the ongoing local urban stratification is sustained through an architectural design that expresses its multi-layered content through all its dimensions ranging from plannimetric spatial configuration and geometric shape grammar to façade treatment and articulation of architectonic massing.

\section{References}

[1] Akgunduz, A., Arsiv Belgeleri Işıgında Tarsus Tarihi ve Eshab-ı Kehf Tarsus Ticaret ve Sanayi Odası: Istanbul, 1993.

[2] Bilgili, A.S., Osmanlı Doneminde Tarsus Sancagl ve Tarsus Turkmenleri; Sosyo-Ekonomik Tarih, Kultur Bakanligi Yayinlari/2657: Ankara, 2001.

[3] Ciplak, M.N., Içel Tarihi; Tarihi Turistik Zenginlikleriyle, Guzel Sanatlar Matbaasi: Ankara, 1968.

[4] Erzen, A., Tarsus Kilavuzu, Maarif Matbaasi: Istanbul, 1943.

[5] Oz, H., Bilinmeyen Tarsus, Kultur Bakanlıg1 Yayinlari 2038: Ankara, 1998.

[6] Clarke, D.L., Analytical Archaeology, London, 1968.

[7] Hodder, I., Reading the Past; Current approaches to Interpretation in Archaeology, Cambridge UP: Cambridge, 1986.

[8] Hyett, P., Building a future for the city of the past. Architect's Journal, 203, p.25, 1996.

[9] Larkham, P.J., Conservation and the City, Routledge: London and New York, 1996.

[10] Boito, C., On Restauratores, Atelier Editorial: Cotia, 2003.

[11] Amorim, L., Loureiro, C., Nascimento, C., Preserving space; towards a new architectural conservation agenda. Proc. of 5th International Space Syntax Symposium, ITU, Istanbul, pp. 032/01-13, 2007.

[12] Pickard, R.D., Conservation in the Built Environment, Addison Wesley Longman Ltd.: London, 1996.

[13] Ruskin, J., Seven Lamps of Architecture, London, 1849.

[14] Schleifer, S., Converted Spaces, Koln, 2006.

[15] Worskett, R., 1984, "New Buildings in Historic Areas; The Missing Ethic", Momentum, V.25, s.29-154.

[16] Thiebaut, P., 2007, Old Buildings Looking for New Use, Stuttgart. 
[17] Warren, J., Worthington, J., Taylor, S. (eds.). Context; New Buildings in Historic Settings, Architectural Press: Oxford, 1998.

[18] Bedard, J.F., Cities of Artificial Excavation; Works of P. Eisenman 197888, Rizzoli: Montreal, 1994.

[19] Borden, I. \& Dunster, D. (eds.). Architecture and the Sites of History; Interpretations of Buildings and Cities, Butterworth: Oxford, 1995

[20] Byard, P.S., Architecture of Additions, W.W. Norton \& Company: London, 1998.

[21] Cantacuzino, S., Re-Architecture; Old Buildings, New Uses, London, 1989.

[22] Cramer, J. \& Breitling, S., Architecture in Existing Fabric; Planning, Design, Building, Birkhauser: Basel, Boston and Berlin, 2007.

[23] Eisenman, P., Written Into the Void, Yale UP: New Haven \& London, 2007.

[24] Groat, L., Contextual compatibility in architecture. Ethnoscapes, ed. D. Canter, et al., Aldershot: Gover, 1988.

[25] Jessen, H. \& Schneider, K., Conversions - the new normal. In Detail: Building in Existing Fabric; Refurbishment, Extensions, New Design, ed. C. Schittich, Birkhauser: Basel, Boston and Berlin, pp.11-21, 2003.

[26] Latham, D., Creative re-use of buildings, Vol. I; principle \& practice, Shaftesbury, 2000.

[27] Mastropietro, M., Restoration \& Beyond; Architecture from Conservation to Conversion, Milan, 1996.

[28] Powell, K., Architecture Reborn; the Conversion and Reconstruction of Old Buildings, London, 1999.

[29] Schittich, C., In Detail: Building in Existing Fabric; Refurbishment, Extensions, New Design, Birkhauser: Basel, Boston and Berlin, 2003.

[30] Çetin, M., "A formal grammar analysis of urban transformation", Unpublished PhD. Thesis, Sheffield University, Department of Architecture, 1999.

[31] Strike, J., Architecture in Conservation, Routledge: New York, 1994.

[32] Hoesli, B., Commentary on Colin Rowe. Transparency, ed. R. Slutzky, Stuttgart, 1968.

[33] Doyduk, S., Akkor, G., La participation de la stratification historique du Tarsus dans le tissue traditionnelle au mémoire public, 1st EuroMediterranean Regional Conference, RehabiMed: Barcelona, 2007.

[34] Amorim, L. \& Loureiro, C., On the spatial dimension of modern architecture as an object of conservation. Proc. of International Seminar on the Management of the Shared Mediterranean Heritage, 5th Conference on the Mediterranean Heritage, IRD: Alexandria, 2005. 